\title{
RESTOCKING Ucides cordatus (DECAPODA: OCYPODIDAE): INTERESPECIFIC ASSOCIATIONS AS A LIMITING FACTOR TO THE SURVIVAL OF RELEASED RECRUITS
}

Robson Ventura ${ }^{1,2^{*}}$, Ubiratã A. T. da Silva ${ }^{1}$, Kelly Cottens $^{1}$, Walter A. Boeger ${ }^{1,4}$ and Antonio Ostrensky ${ }^{1,3}$

${ }^{1}$ Universidade Federal do Paraná - Grupo Integrado de Aquicultura e Estudos Ambientais (Rua dos Funcionários, 1540, 80035-050 Curitiba, PR, Brasil)

${ }^{2}$ Centro de Desenvolvimento em Aqüicultura e Pesca - CEDAP/EPAGRI (Rodovia Admar Gonzaga, 1.118, 88034-901 Florianópolis, SC, Brasil)

${ }^{3}$ Universidade Federal do Paraná - Departamento de Zootecnia (Rua dos Funcionários, 1540, 80 035-050 Curitiba, PR, Brasil)

${ }^{4}$ Universidade Federal do Paraná - Departamento de Zoologia, Setor de Ciências Biológicas (Centro Politécnico, Jardim da Américas, C. P.: 190-31, Curitiba, PR, Brasil)

*Corresponding author: robson.ventura@gmail.com

\section{A B S T R A C T}

Simulations in the laboratory were used to investigate whether survivorship rates of Ucides cordatus youngsters produced in the laboratory are significantly affected by other crab species after their release in natural environments. Furthermore, it was investigated whether the release of first instar juveniles instead of megalopae would reduce the mortality related to interspecific predation. A preliminary estimate of the crab community structure in the target area of a restocking program was undertaken and indicated a great dominance of fiddler crabs (Uca spp). Based on this information, experiments were conducted to assess the ecological relationship between Ucides cordatus megalopae and first instar juveniles and fiddler crabs of different size classes in the presence of mangrove sediment, simulating natural conditions, as well as in the absence of any kind of refuge. It was observed that fiddler crabs not only compete with, and prey on $U$. cordatus youngsters, both as megalopae and juveniles. Furthermore, it was observed that the predation behavior of fiddler crabs is exercised only by individuals with carapaces wider than $0.5 \mathrm{~cm}$. The results of the assay simulating natural conditions showed that, even when sediment was provided as a refuge, the same pattern was observed, with survivorship rates significantly lower in the presence of $U c a$ crabs.

\section{RESUMO}

Simulações em laboratório foram efetuadas visando investigar se após liberação na natureza a sobrevivência de recrutas de Ucides cordatus produzidos em laboratório é afetada por outras espécies de caranguejos. Adicionalmente, foi verificado se com a liberação de juvenis no estágio 1 , ao invés de megalopas, haveria redução da mortalidade causada por predação interespecífica. Para tanto foi realizada estimativa prévia da estrutura da comunidade de caranguejos presente na área-alvo de um programa de repovoamento em desenvolvimento na região de Santo Amaro, Baía de Todos os Santos, Brazil, cujos resultados mostraram grande dominância de caranguejos violinista (Uca spp.). Com base nessa informação, foram realizados experimentos para verificar as relações ecológicas entre megalopas e juvenis 1 de Ucides cordatus e as diferentes classes de tamanho das outras espécies de $U c a$, em presença de sedimento do mangue, simulando condições naturais, e na ausência de refúgio. Observou-se que os caranguejos violinista competem predando tanto juvenis quanto megalopas de Ucides cordatus. Além disso, foi visto que esse comportamento de predação é exercido apenas por indivíduos com largura de carapaça maior que $0,5 \mathrm{~cm}$. Os resultados do teste de simulação das condições do ambiente natural evidenciaram que o mesmo padrão de predação foi observado mesmo quando o sedimento foi oferecido como refúgio, sendo as taxas de sobrevivência significativamente menores na presença de espécies de $U c a$.

Descriptors: Predation, Fiddler crab, Sediment, Release.

Descritores: Predação, Caranguejo-violinista, Sedimento, Liberação. 


\section{INTRODUCTION}

The mangrove crab Ucides cordatus, locally known as "caranguejo-uçá" in Brazil, is widely distributed geographically along the western Atlantic coast, from Florida (USA) to the Brazilian state of Santa Catarina. This crab is considered an important fishery resource for local populations all along the Brazilian coast, particularly for those living in proximity to estuarine systems (GLÄSER, 2003).

In Brazil, a technology for the restocking of the species has been under development since 2001 The consolidation of this technology has recently gained greater significance for the conservation of the species due to mass mortality events in populations of the northeastern and southeastern Brazilian mangrove forests (SILVA et al., 2006). These events have been associated with a disease caused by an as yetundescribed species of black yeast fungi and which has been called the Lethargic Crab Disease (LCD) by Boeger et al. (2005). Associated with other factors, such as overexploitation and mangrove habitat degradation, the LCD has contributed to the drastic reduction of the natural stocks of $U$. cordatus on the Brazilian coast.

A basic technology for $U$. cordatus larviculture is already known and restocking programs performed by Grupo Integrado de Aquicultura e Estudos Ambientais (GIA) have been able to produce more than 1000000 megalopae systematically per reproductive season (SILVA et al., 2006, 2009). However, our knowledge of post-release events needs to be enhanced in order to optimize the success of the entire process of restocking. The behavior of the released larvae and their relation to natural factors, such as interspecific competition and predation, is one of the important issues that requires a better understanding so as to allow corrective feedback.

Currently, Ucides cordatus youngsters produced by restocking programs are released when they reach the megalopa phase. As observed with regard to Callinectes sapidus and Portunus trituberculatus (SECOR et al., 2002), success in the use of immature portunid crabs reared in the laboratory for restocking purposes depends largely on their age at the moment of release into the natural environment. Recent studies have suggested that the release of juveniles of the mangrove crab $U$. cordatus, might also be more effective in view of their putative reduced susceptibility to predation by fish and their greater ability to compete with crabs of other species (VENTURA et al., 2008).

Thus, this study investigated whether survivorship rates of $U$. cordatus youngsters after release are significantly affected by the presence of other crab species. Further, we investigated if the release of more developed young forms could reduce the mortality related to the competition/predation factor.

\section{Material and Methods}

Study of the Structure of the Crab Communities

We studied the population structure of the crab communities of a mangrove target area for the restocking program, before any release had been undertaken. The target area was located in Santo Amaro, state of Bahia, Brazil (Fig. 1). The population structure was estimated using a wooden quadrant $(0.4$ x $0.4 \times 0.2 \mathrm{~m}$ ). This quadrant was randomly thrown over the mangrove area. A $15 \mathrm{~cm}$ deep layer of sediment was removed from the area delimited by the quadrant, and sieved in the laboratory. Five samples were collected at the site and all the collected crabs were identified and measured (carapace width-CW).

Based on the results of this estimate, two assays were designed (see below). These assays were developed in an environmental room under controlled temperature $\left(26^{\circ} \mathrm{C}\right)$ and photoperiod $(16: 8 \mathrm{~h} \mathrm{LD}$ cycle).

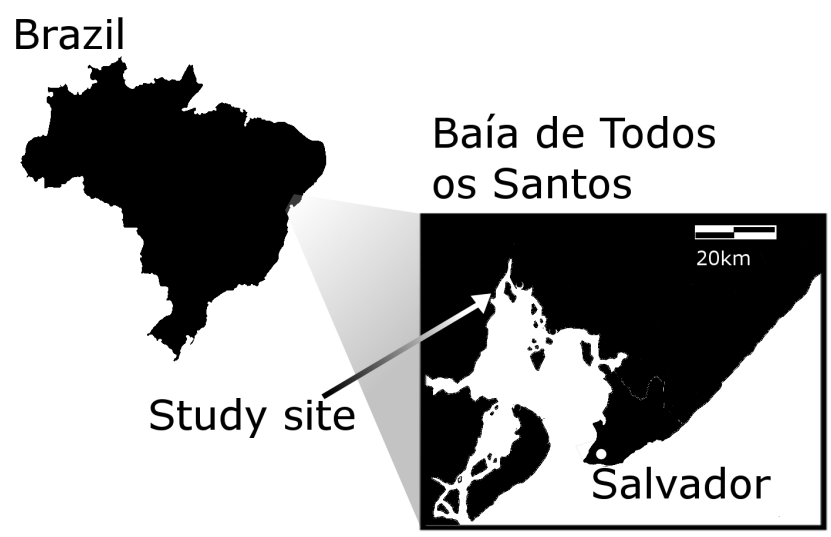

Fig. 1. Location where the crab structure estimation was carried out. 
Relationship of Fiddler Crabs and Youngsters of Ucides cordatus

An assay was performed to determine how fiddler crabs (Uca spp.) of different width classes could affect the survivorship of $U$. cordatus youngsters as megalopae and in the juvenile phase. The fiddler crabs used in the experiments were collected in the same mangrove area in which the structure of the crab community was estimated. No special distinction in terms of sex ratio was made for the fiddler crabs used in this test; both male and female crabs were used randomly.

Transparent plastic vials, with dimensions of $11 \times 11 \times 5 \mathrm{~cm}$, containing $0.5 \mathrm{~L}$ of salt water were used as experimental units. No substrates of any kind were used in this set of experiments. Three distinct fiddler crab CW classes were evaluated: $0-0.5 \mathrm{~cm}$ width; 0.5 $1 \mathrm{~cm}$ width and $1-1.5 \mathrm{~cm}$ width. The treatments used are described below. For convenience, they will be distinguished as follows:

M control - Five $U$. cordatus megalopae $\mathrm{J}$ control - Five $U$. cordatus juveniles M 0-0.5 - Five megalopae + one 0-0.5 cm Uca sp. J 0-0.5 - Five juveniles + one 0-0.5 cm Uca sp. M 0.5-1 - Five megalopae + one 0.5-1 cm Uca sp. J 0.5-1 - Five juveniles + one 0.5-1 cm Uca sp. M 1-1.5 - Five megalopae + one 1-1.5 cm Uca sp. J 1-1.5 - Five juveniles + one 1-1.5 cm Uca sp.

All treatments, including those of the control groups, were tested with five replicates. No food was supplied. After 24 hours, the survivorship rates of the young forms of $U$. cordatus and of the fiddler crab were determined.

\section{Assays Simulating Natural Conditions}

An experiment simulating natural conditions was developed in the laboratory. Ten transparent plastic boxes, with dimensions $20 \times 32 \times 25 \mathrm{~cm}$, provided with an individual draining system, were used as experimental units. In this set of experiments, mangrove sediment was used as substrate. The bottom of the boxes was covered with a $7 \mathrm{~cm}$ layer of sediment, to simulate a natural refuge. Equal volumes of seawater (salinity 35, filtered with $0.5 \mu \mathrm{m}$ sand filter, sterilized with a UV device) were provided for each individual unit.

The fiddler crabs were released in the experimental units in the following proportion: 2 individuals of $0-0.5 \mathrm{~cm}$ width; 5 individuals of $0.5-1$ $\mathrm{cm}$ width and one of $1-1.5 \mathrm{~cm}$ width. The young forms of $U$. cordatus were only released into the boxes on the following day. The water level was raised 15 $\mathrm{cm}$ above the sediment layer and all units (control group, containing only mangrove sediment, and the treated ones, containing fiddler crabs) received $20 \mathrm{U}$. cordatus youngsters. The water level was maintained high during the first 3 hours after the release of $U$. cordatus, after which the units were completely drained.

The water level inside all the units was raised, daily, above the sediment surface for 3 hours, to simulate high tide. During this simulation period, newly hatched artemia nauplii were provided at a density of 0.3 individuals. $\mathrm{ml}^{-1}$. The experiment was terminated after 20 days and all the sediment of each unit was carefully sieved. All the living fiddler crabs and $U$. cordatus juveniles were counted and the survivorship rates determined.

\section{Statistical Analysis}

Given that a Shapiro-Wilk test indicated that the data from the experiments did not deviate significantly from normality, all the analyses were carried out using parametric statistics. ANOVA, followed by Fisher's LSD or Tukey's HSD post-hoc tests, were used to detect significant differences between the survivorship rates observed among the various treatments used.

\section{RESULTS}

\section{Structure of the Crab Communities}

One-hundred and four crabs were captured in the 5 samplings: 100 of them belonging to species of $U c a$ (average carapace width, CW: $0.75 \mathrm{~cm}, \sigma$ $0.29 \mathrm{~cm}), 3$ U. cordatus $(\mathrm{CW} 0.8 \mathrm{~cm} ; 1 \mathrm{~cm} ; 1.3 \mathrm{~cm})$ and 1 Aratus pisoni $(\mathrm{CW} 0.7 \mathrm{~cm})$. In three of the samples, only fiddler crabs were identified. The carapace-width frequency distribution of fiddler crabs is presented in Figure 2.

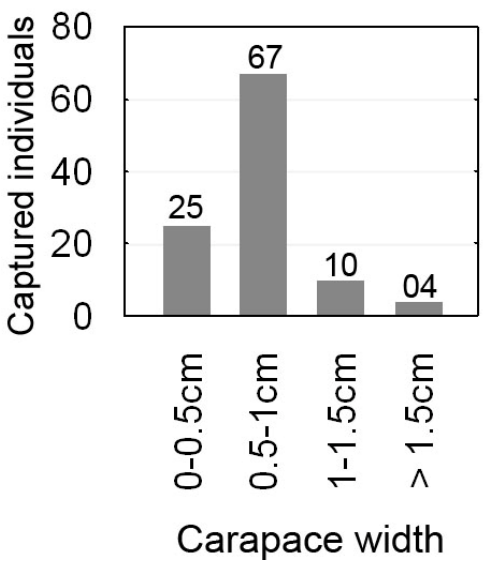

Fig. 2. Frequency distribution of carapace width (CW) of all fiddler crabs collected in a target area of the $U$. cordatus restocking program, in Santo Amaro, Bahia, Brazil, before the release of cultivated $U$. cordatus. 
Relationship of Fiddler Crabs and Youngsters of Ucides cordatus

All the fiddler crab individuals released into the experimental units survived. No differences between survivorship rates of $U$. cordatus megalopae and juveniles were observed in any of the treatment or control groups. Survivorship rates of $U$. cordatus young forms observed in the control groups were not significantly different from those obtained in treatments $\mathrm{M} \quad 0-0.5$ and $\mathrm{J} 0-0.5$. However, the survivorship rates of treatments $\mathrm{M} 0.5-1 \mathrm{~cm}, \mathrm{~J} 0.5-1$, M $1-1.5$ and $J 1-1.5$ were lower $(n=40, F=28.62$, $\mathrm{p}<0.0001$ ) than those of the control groups (Fig. 3). In the treated units in which mortality was observed, no remains of dead $U$. cordatus youngsters were found after only 24 hours, indicating predation by the fiddler crabs.

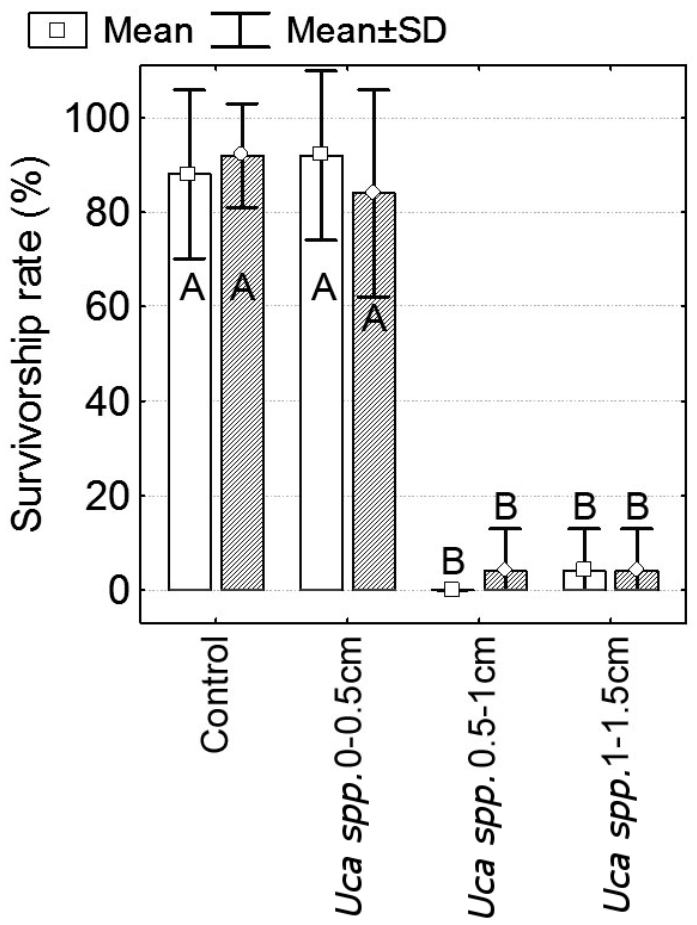

Fig. 3. Effect of presence of fiddler crabs of different carapace width on the survivorship rates of $U$. cordatus youngsters in a limited environment without shelter. White bars represent treatments using megalopae and gray bars represent juvenile survival rates. Letters above bars indicate homogeneous groups according to Tukey's HSD test.

\section{Experiments Simulating Natural Conditions}

The survivorship rates observed for $U$. cordatus megalopae as well as for juveniles in the treatments occupied by fiddler crabs were significantly lower $(\mathrm{N}=20, \mathrm{~F}=10.35, \mathrm{P}=0.0004)$ than those observed for either in the control groups. No significant differences $(p>0.05)$ were detected either between control groups, or between the treatments (Fig. 4).

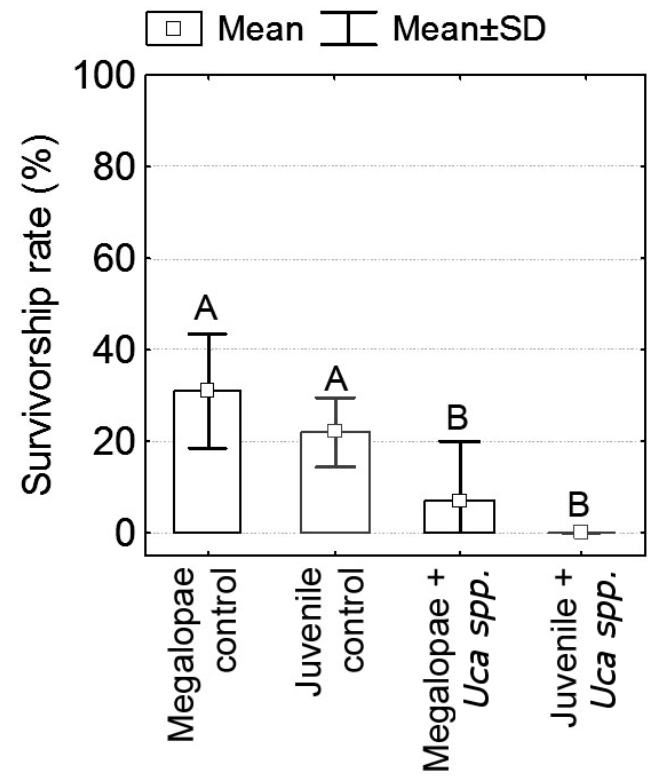

Fig. 4. Effect of presence of fiddler crabs on the survivorship rates of $U$. cordatus youngsters in a natural refuge simulating environment. Letters above bars indicate homogeneous groups according to Fisher's LSD test.

\section{DisCUSSION}

The community structure of the mangrove area studied showed a great dominance of fiddler crabs (Uca spp.). Indeed, other authors (MASUNARI, 2006) have reported the abundance of these crabs in Brazilian mangrove swamps. According to Crane (1975), fiddler crabs compose a significant portion of the macrofaunistic biomass of the intertidal zone and, given their great abundance in estuarine areas, their feeding activities are considered.

One of the most important factors influencing nutrient mineralization and ecological transference to the food chain in these habitats (MONTAGUE, 1980).

The diet of fiddler crabs is based on benthic microflora, such as bacteria, diatoms and blue algae associated with organo-mineral substrates (CRANE, 1975). These crabs are commonly cited as prey for a variety of animals such as mammals, birds and fish (MASUNARI, 2006) and even as competitors of $U$. cordatus settlers (SILVA, 2006). However, it has not been possible to find any reports on the predation behavior of fiddler crabs in the literature. Our results 
show that fiddler crabs play an important role as predators of U.cordatus crab settlers. We observed that these crabs can prey actively on young forms of $U$. cordatus whether in the megalopa or juvenile phase. Interspecific predation on settlers has also been described in studies conducted with crabs of other species, such as Cyrtograpsus angulatus, Chasmagnathus granulata (LUPPI et al., 2001) and Panopeus herbstii (DITTEL et al., 1996).

Burrowing is commonly cited as an important behavior to avoid predation of post-larvae of many aquatic organisms, such as the lobster Homarus americanus (see Barshaw and Lavalli, 1988), as well as crab species (HECK; HAMBROOK, 1991; OLMI; LIPCIUS, 1991; DITTEL et al., 1996; MOKSNES et al., 1997; HEMMI, 2005; ZEIL; HEMMI, 2006), including U. cordatus (BRANCO, 1993). Luppi et al. (2001), studying interspecific relations of $C$. angulatus and $C$. granulata, report that the access of the predator to the prey's refuge is an important factor which affects the mortality due to predation on settlers.

In our first experiment relating to predation, no substrates were provided for $U$. cordatus youngsters and they were thus incapable of burrowing or hiding. It is therefore possible that the mortality rates registered in this experiment were much higher than would be observed under natural conditions. On the other hand, the results of the experiment simulating natural mangrove habitats showed that, even when sediment was provided as a refuge, a similar pattern was observed, with survivorship rates significantly lower in the presence of fiddler crabs. Based on these results, it is possible to suggest that in natural environments the predation practised by fiddler crabs is a key factor influencing the recruitment of $U$. cordatus.

Furthermore, the results of this study show that the release of young forms during the juvenile phase, specifically in stage 1 , did not significantly reduce mortalities due to interspecific predation. In both experiments, those conducted without substrates and those simulating natural conditions, juveniles showed survivor performances similar to those of individuals in the megalopa phase.

One of the most important patterns observed in our study showed that the predation of fiddler crabs on young forms of $U$. cordatus was practised only by individuals with $\mathrm{CW}$ larger than $0.5 \mathrm{~cm}$. Bearing in mind that the whole assay lasted for only 24 hours, it is possible to suppose that even smaller fiddler crabs would eventually prey on $U$. cordatus youngsters after a longer period. However, this pattern is an indication that size difference between fiddler crabs and young forms of $U$. cordatus (first instar crab $\mathrm{CW}=1.71 \mathrm{~mm}$, Dielle, 2000) is a factor limiting predation. Previous studies of the interactions between prey and predators of different sizes have indicated prey size as one of the determining factors when the prey is a crab species (BEHRENS YAMADA; BOULDING, 1998; LUPPI et al., 2001).

Considering that most fiddler crabs found in the study area were smaller than $1 \mathrm{~cm}$ (carapace width), it is possible to hypothesize that releasing $U$. cordatus juveniles with larger $\mathrm{CW}$ would be a possible way of reducing mortality due to predation by fiddler crabs.

Evaluating the effectiveness of the restocking of the Japanese Portunus trituberculatus (MIERS, 1876) programs, Ariyama (2000) conducted a series of intensive release-recapture trials of laboratory produced recruits and concluded that releasing first instar juveniles $(\sim 5 \mathrm{~mm} \mathrm{CW})$ resulted in no settled crab one week after release. In contrast, he found that by releasing instar IV juveniles $(\sim 17 \mathrm{~mm}$ $\mathrm{cw})$ it was possible to reach satisfactory survivorship rates (30\% of survivorship one month after release). This author attributed the results obtained to the higher susceptibility of juvenile I to predation by fishes and other crabs. To obtain instar IV juveniles, Japanese researchers had to implement a secondary rearing phase in their restocking methodology (SECOR et al., 2002).

In the light of this information and the results of our experiments, we recommend that efforts to restock $U$. cordatus should consider the possibility of the implementation of a secondary rearing phase, in which juveniles might achieve a suitable size to protect themselves from predation, in order to enhance the effectiveness of the process. Furthermore, investigations of optimum release sizes of $U$. cordatus juveniles still need to be undertaken to determine for how long this second rearing phase should last, considering the naturally slow growth rate of $U$. cordatus.

\section{REFERENCES}

ARIYAMA, H. Studies on Ecology and Stock Enhancement of Swimming Crab Portunus trituberculatus in Osaka Bay. Bull. Osaka Prefect. Fish. expl. Stat. , v. 12, p. 1 $-90,2000$.

BARSHAW, D. E.; LAVALLI, K. L. Predation upon postlarval lobsters, Homarus americanus, by cunners, Tautogolabrus adspersus, and mud crabs, Neopanope sayi, on three different substrates: eelgrass, mud, and rocks. Mar. Ecol. Prog. Ser., v. 48, p. 119-123, 1988.

BEHRENS YAMADA, S.; BOULDING, E. G. Claw morphology, prey size selection and foraging efficiency in generalist and specialist shell-breaking crabs. J. expl mar. Biol. Ecol., v. 220, p. 191-211, 1998.

BOEGER W. A.; PIE M. R.; OSTRENSKY A.; PATELLA L. Lethargic crab disease: multidisciplinary evidence supports a mycotic etiology. Mem. Inst. Oswaldo Cruz, v. 100, n. 2 , p. 161-167, 2005. 
BRANCO, J. O. Aspectos bioecológicos do caranguejo Ucides cordatus (Linnaeus, 1763) (Crustacea, Decapoda) do manguezal de Itacorubi, Santa Catarina, Br. Arq. Biol. Tecnol., v. 36, p. 133-148, 1993.

CRANE, J. Fiddler crabs of the world, Ocypodidae: genus Uca. Princeton: Princeton University Press, $1975.736 \mathrm{p}$

DITTEL, A.; EPIFANIO, C. E.; NATUNEWICZ, C Predation on mud crab megalopae, Panopeus herbstii , H. Milne Edwards: effect of habitat complexity, predator species and postlarval densities. J. expl mar. Biol. Ecol., v. 198, p. 191-202, 1996.

GLÄSER, M. Interrelations between mangrove ecosystem, local economy and social sustainability in Caeté Estuary, North Brazil. Wetl. Ecol. Manag., v.11, n. 4, p. 265272, 2003

HECK JR., K. L.; HAMBROOK J. A. Intraspecific interactions and risk of predation for Dyspanopeus sayi (Decapoda: Xanthidae) living on polychaete (Filograna implexa Serpulidae) colonies. Mar. Ecol. Prog. Ser., v. 12, n. 3, p. 243-250, 1991

HEMMI, J. M. Predator avoidance in fiddler crabs: Escape decisions in relation to the risk of predation. Anim. Behav., v. 69, p. 603-614, 2005.

LUPPI, T. A.; SPIVAK, E. D.; ANGER, K. Experimental studies on predation and cannibalism of the settlers of Chasmagnathus granulata and Cyrtograpsus angulatus Brachyura: Grapsidae. J. expl mar. Biol. Ecol., v. 265, p. 29-48, 2001.

MASUNARI, S. Distribuição e abundância dos caranguejos Uca Leach (Crustacea, Decapoda, Ocypodidae) na Baía de Guaratuba, Paraná Brasil. Rev. Bras. Zool. v. 23, n. 4, p. 901-914, 2006.

MOKSNES, P. O.; LIPCIUS, R. N., PIHL, L.; VAN MONTFRANS, J. Cannibal-prey dynamics in juveniles and postlarvae of the blue crab. J. expl mar. Biol. Ecol., v. 215 , p. $157-187,1997$.

MONTAGUE, C. L. A natural history of temperate western Atlantic fiddler crabs (Genus Uca) with reference to their impact on salt marsh. Contr. mar. Sci., v.23, p.25-55, 1980.
OLMI, E. J.; LIPCIUS, R. N. Predation on postlarvae of the blue crab Callinectes sapidus Rathbun by sand shrimp Crangon septemspinosa Say and grass shrimp Palaemonetes pugio Holthius. J. expl mar. Biol. Ecol., v. 151 , p. $169-183,1991$.

SECOR, D. H.; HINES, A. H.; PLACE, A. R. Japanese Hatchery-based stock enhancement: Lessons for the Chesapeake Bay Blue Crab. Maryland: Sea Grant Publication Number UM-SG-TS-2002-02, 2002. 46 p.

SILVA, U. A. T.; OSTRENSKY, A.; VENTURA, R.; SANTOS, A. F.; BOEGER, W. A. A produção de caranguejo-uçá em laboratório. Panorama da Aqüicultura v. 16, v. 94, p. 15-21, 2006.

SILVA, U. A. T.; MENEZES, F. R.; SOUZA, R. V.; COELHO NETO, A.; BOEGER, W. A.; OSTRENSKY, A. A aqüicultura a serviço da conservação: A produção de larvas de caranguejo-uçá em sistema de cultivo em mesocosmos. Panorama da Aqüicultura, v. 113, p. 24$31,2009$.

VENTURA, R.; SILVA, U. A. T.; PERBICHE-NEVES, G.; OSTRENSKY, A.; BOEGER, W. A.; PIE, M. R. Duration of the pre-settlement period of the Mangrove Crab Ucides cordatus (Decapoda: Ocypodidae) under laboratory conditions. Braz. Arch. Biol. Techn., v. 51 (5), p. 957-962, 2008.

ZEIL, J.; HEMMI, J. M. The visual ecology of fiddler crabs. J. comp. Physiol., v.192, p.1-25, 2006.

(Manuscript received 18 September 2009; revised 31 March 2010; accepted 14 April 2010) 